\title{
Analisis Faktor-Faktor yang mempengaruhi Ambulasi Dini Post ORIF pada Pasien Fraktur Femur Study Retrospektif
}

\author{
Giat Wantoro $^{1}$, Muflihatul Muniroh ${ }^{2}$, Henni Kusuma ${ }^{3}$ \\ ${ }^{1}$ Prodi SI Keperawatan STIKes Baiturrahim Jambi \\ ${ }^{2}$ Prodi SI KedokteranUNDIP Semarang \\ ${ }^{3}$ Prodi S1 Keperawatan UNDIP Semarang \\ Email: giatwantoro@gmail.com
}

Submitted : 06/08/2020

Accepted: 20/08/2020

Published: 07/09/2020

\begin{abstract}
Femur fracture is a loss of continuity of the femur, which can be caused by direct trauma to the thigh or pathological factors. The main treatment for fractures is ORIF. Implementation of early ambulation is important to prevent post ORIF complications. Objective: This study aims to analyze the factors that influence early ambulation post ORIF in femoral fracture patients. Methods: The study design was a cross-sectional retrospective approach with 82 respondents and data collection using medical record data. The independent variables are education, sex, age, hemoglobin, temperature, blood pressure, pain, fracture location, and time span of operation while the dependent variable is early ambulation. The test used in multivariate is logistic regression test. Results and discussion: Research shows education $(p=0,000)$, gender $(p=0.028)$, age $(p=$ $0,000), \mathrm{Hb}(p=0.029)$, pain $(p=0.001)$, and location of the fracture $(p=0.007)$, is an influential factor. The multivariate model found the fracture location to be the most influencing factor in post ORIF early ambulation in femur fracture patients with $p=0.023$ and an OR value of 2.140. Conclusion: This study recommends that nurses first examine the factors that influence early ambulation, especially fracture location factors before providing post ORIF early ambulation interventions in femur fracture patients.
\end{abstract}

Keywords: early ambulation, femoral fracture, post ORIF

\begin{abstract}
Abstrak
Fraktur femur merupakan hilangnya kontinuitas tulang paha, yang dapat disebabkan oleh trauma langsung pada paha ataupun faktor patologis. Penatalaksanaan utama pada fraktur adalah ORIF. Pelaksanaan ambulasi dini menjadi penting untuk mencegah terjadinya komplikasi post ORIF. Tujuan: Penelitian ini bertujuan menganalisis faktor-faktor yang mempengaruhi ambulasi dini Post ORIFP ada Pasien Fraktur Femur. Desain penelitian adalah cross-sectional pendekatan retrospektif dengan 82r esponden dan pengumpulan data menggunakan data rekammedik.Variabel independen adalah pendidikan, jenis kelamin, usia, $\mathrm{Hb}$, suhu,tekanan darah, nyeri, lokasifraktur, dan waktu rentang operasi sementara variable dependen adalah ambulasi dini. Uji yang digunakan pada multivariat adalah uji regresilogistic. Hasil dan pembahasan: Penelitian menunjukan pendidikan $(p=0,000)$, jenis kelamin $(p=0,028)$, usia $(p=0,000), \mathrm{Hb}(p=0,029)$,nyeri $(\mathrm{p}=0,001)$, dan lokasi fraktur $(\mathrm{p}=0,007)$, adalah faktor yang berpengaruh. Model multivariate didapatkan faktor lokasi fraktur menjadi faktor yang paling mempengaruhi ambulasi dini post ORIF padapasienfraktur femur dengan $p=0,023$ dan nilai OR 2.140. Kesimpulan: Penelitian ini menyarankan perawat mengkaji terlebih dahulu faktor yang mempengaruhi ambulasi dini khususnya faktor lokasi fraktur sebelum memberikan intervensi ambulasi dini post ORIF pada pasien fraktur femur.
\end{abstract}

Kata Kunci :ambulasidini, fraktur femur, post ORIF 


\section{PENDAHULUAN}

Fraktur femur merupakan diskontinuitas dari femoral shaft yang bisa terjadi akibat trauma baik secara langsung ataupun tidak langsung dan apabila terjadi patah pada tulang ini bisa menimbulkan perdarahan yang cukup banyak bahkan bisa mengakibatkan syok, morbiditas yang lama dan juga kecacatan apabila tidak mendapatkan penanganan yang baik.Diantara pasien fraktur femur terdapat $1 \%$ yang menderita kecacatan menetap dan $30 \%$ mengalami kecacatan yang bersifat sementara.Fraktur saat ini merupakan penyakit muskuloskeletal yang banyak di jumpai di pusat-pusat pelayanan kesehatan di seluruh duniaObaidurrahman,et,all (2013).

Insiden fraktur di dunia menurut WHO terdapat 21 juta orang.Sementara di Indonesia sekitar 8 juta orang mengalami kejadian fraktur dengan jenis fraktur yang berbeda dan penyebab yang berbeda.Di Provinsi Jawa Tengah angka kejadian fraktur juga cukup tinggi yaitu sebanyak 496.000 kasus. Berdasarkan data dari Rekam Medik RSU Siaga Medika Banyumas jumlah pasien fraktur yang dirawat inap pada tahun 2019 sebanyak 2914 orang, dan persentase fraktur femur menjadi yang terbanyak dibandingkan dengan fraktur yang lain yaitu sebesar 39\% Depkes RI (2013).

Penatalaksanaan utama yang sering dilaksanakan pada kasus fraktur femur untuk memulihkan fungsi normal adalah tindakan pemasangan Open Reduction Internal fixatie (ORIF). ORIF adalah sebuah prosedur bedah medis, yang tindakannya mengacu pada operasi terbuka untuk mengatur tulang kembali pada posisi anatominya.Fiksasi internal mengacu pada fiksasi Plate and Screw untuk memfasilitasi penyembuhanBrunner\&Sudarth(2010).

Penatalaksanaan bedah patah tulang ini paling banyak keunggulannya seperti ketelitian reposisi fragmen-fragmen tulang yang patah,kesempatan untuk memeriksa pembuluh darah dan saraf yang berada didekatnya,dapat mencapai stabilitas fiksasi yang memadai, dan tidak perlu berulang kali memasang gips atau alat-alat stabilisasi lainnyaPrice \& Wilson, (2012).

Permasalahan yang timbul dari tindakan ORIF berkaitan dengan nyeri, gangguan perfusi jaringan, gangguan mobilitas fisik, dan gangguan konsep diri.Penatalaksanaan fraktur tersebut dapat mengakibatkan masalah atau komplikasi seperti baal, nyeri, kekakuan otot, bengkak atau edema, keterbatasan lingkup gerak, penurunan kekuatan otot, penurunan aktivitas fungsional serta pucat pada anggota gerak yang di operasi.Masalah tersebut dapat dicegah dengan ambulasi dini pasca pembedahanSmeltzer\& Bare (2013).

Mobilisasi dini merupakan usaha atau kemampuan pasien setelah operasi untuk bergerak dengan tujuan untuk memenuhi kebutuhan aktivitas guna mempertahankan kesehatannya sesuai dengan kondisi pasien tersebut. Beberapa literatur menyebutkan bahwa pentingnya melakukan mobilisasi dini yaitu untuk memperbaiki sirkulasi, mencegah terjadinya masalah atau komplikasi setelah operasi serta mempercepat proses pemulihan pasien. Hasil dari beberapa penelitian menunjukan bahwa ambulasi dini meningkatkan pemenuhan Activity of Daily Living (ADL),memperpendek lama hari rawat pasien post ORIF, selanjutnya ambulasi dini juga meningkatkan kekuatan otot dan mengurangi nyeriKeehan, ett,all ( 2014).

Hampir semua jenis pembedahan, setelah 24 jam dianjurkan untuk melakukan mobilisasi sesegera mungkin.Kenyataannya tidak semua pasien setelah pembedahan dapat segera melakukan mobilisasi dini, umumnya pasien post operasi setelah 24 jam lebih memilih untuk diam ditempat tidur (bedrest)Smeltzer \& Bare (2013). Hasil penelitian Tita menunjukan bahwa implementasi mobilisasi dini yang dilakukan oleh perawat pada pasien post ORIF fraktur ekstremitas bawah yaitu perawat melakukan mobilisasi dini 
sebanyak 16 dan tidak melakukan sebanyak 15 dari 30 responden. Sedangkan penelitian Satiadidapatkan 26 dari 30 responden tidak melakukan mobilisasi dini.

Pelaksanaan mobilisasi dini dapat dipengaruhi oleh beberapa faktor yaitu pengetahuan, pendidikan, dukungan sosial,status perkembangan (usia dan jenis kelamin), faktor fisiologis (lokasifraktur dannyeri) faktor status mental (cemas dan motivasi).Kebanyakan pasien merasa takut untuk bergerak paska operasi fraktur karena merasa nyeri pada luka bekas operasi dan luka bekastrauma. Selanjutnya efek dari ORIFdapat menimbulkan hipotensi ortostatik dimana pasien mengalami ketidakmampuan berat dengan karakteristik tekanan darah yang. Anemia mungkin terjadi paska ORIF yang dapat mempengaruhi pasien pada saat latihan fisik dikarenakan cepat lelah, takikardi, palpitasi dan takipnea, perubahan status kesehatan dapat mempengaruhi sistem musculoskeletal dan sistem saraf berupa penurunan koordinasi yang mengakibatkan berkurangnya kemampuan seseorang untuk melakukan aktifitas dan latihan. Hasil penelitian lain menyatakan bahwa faktor pendidikan dan usia menyebabkan perubahan pada kemampuan intelektual yang mempengaruhi perilaku dan memberikan gambaran korelasi yang signifikan dengan indeks kemandirianPotter\& Perry (2010). Kemudian operasi yang dilakukan sedini mungkin dalam 24 hingga 36 jam paska admisi ke rumah sakit memiliki indeks kemandirian aktifitas sehari hari yang lebih baik dibandingkan dengan operasi yang tertunda.

Hasil observasi dan wawancara yang dilakukan di Rumah Sakit Umum Siaga Medika Banyumas, didapatkan jumlah pasien ORIF tahun 2019 bulan (JanuariOktober) sebanyak 632 pasien, dari jumlah tersebut kasus fraktur femur menempati jumlah terbanyak yaitu 309 pasien, berdasarkan lokasinya fraktur femur proksimal menempati urutan tertinggi yaitu 187 dan jenis kelamin terbanyak adalah laki-laki dan usia paling banyak adalah diatas 31 tahun. Perawat menyatakan bahwa pasien dianjurkan melaksanakan ambulasi dini pada 24 jam post ORIF. Dari 5 pasien fraktur femur yang dilakukan tindakan ORIF, sebanyak 4 pasien belum berani melakukan ambulasi dini pada 24 jam pertama setelah tindakan ORIF. Mereka mengatakan merasa takut untuk bergerak karena merasa nyeri, 2 dari 5 pasien dilakukan tindakan ORIF setelah berobat ke alternatif.

Berdasarkan faktor-faktor yang mempengaruhi ambulasi dini dan hasil survey pendahuluan maka penulis tertarik untuk melakukan penelitian tentang faktorfaktor yang mempengaruhi ambulasi dini post ORIF pada pasien fraktur femur.

\section{METODE PENELITIAN}

Jenis penelitian ini merupakan penelitian analitik non-eksperimental dengan rancangan penelitian cross-sectional pendekatan retrospektif. Variabel dependen pada penelitian ini adalah ambulasi dini sedangkan variabel independen penelitian antara lain: karakteristik pasien, status kesehatan dan faktor fisiologis. Populasi pada penelitian ini semua pasien post ORIF pada fraktur femur cara pengambilan sampel menggunakan consecutive sampling dan besar sampel adalah 82 responden yang sesuai dengan kriteria inklusi. Analisa data yang digunakan adalah univariat, bivariat menggunakan uji chi-aquare dan multivariat dengan uji regresi logistik. 


\section{HASIL DAN PEMBAHASAN}

\section{A. Univariat}

Tabel 1. Distribusi frekuensi responden

\begin{tabular}{|c|c|c|}
\hline Variable & f & $\%$ \\
\hline \multicolumn{3}{|l|}{ Pendidikan } \\
\hline SD & 31 & 37,8 \\
\hline SMP & 10 & 12,2 \\
\hline SMA & 33 & 40,2 \\
\hline PT & 8 & 9,8 \\
\hline \multicolumn{3}{|l|}{ Jenis Kelamin } \\
\hline Laki-laki & 47 & 57,3 \\
\hline Perempuan & 35 & 42,7 \\
\hline \multicolumn{3}{|l|}{ Usia } \\
\hline Remaja & 10 & 12,2 \\
\hline Dewasa & 49 & 59,8 \\
\hline Lansia & 23 & 28,0 \\
\hline \multicolumn{3}{|l|}{ HB } \\
\hline Normal & 11 & 13,4 \\
\hline Anemia & 71 & 86,6 \\
\hline \multicolumn{3}{|l|}{ Suhu } \\
\hline Hipotermi & 3 & 3,7 \\
\hline Normal & 78 & 95,1 \\
\hline Hipertermi & 1 & 1,2 \\
\hline \multicolumn{3}{|l|}{ Tekanan Darah } \\
\hline Normotensi & 62 & 75,6 \\
\hline Hipotensi & 5 & 6,1 \\
\hline Hipertensi & 15 & 18,3 \\
\hline \multicolumn{3}{|l|}{ Nyeri } \\
\hline Ringan & 12 & 14,6 \\
\hline Sedang & 50 & 61,0 \\
\hline Berat & 20 & 24,4 \\
\hline \multicolumn{3}{|l|}{ Lokasi Fraktur } \\
\hline Proksimal & 39 & 47,6 \\
\hline Medial & 25 & 30,5 \\
\hline Distal & 18 & 22,0 \\
\hline \multicolumn{3}{|l|}{ W.R.O } \\
\hline Cepat & 48 & 58,5 \\
\hline Lambat & 34 & 41,5 \\
\hline \multicolumn{3}{|l|}{ Ambulasi Dini } \\
\hline Tidak dilakukan & 40 & 48,8 \\
\hline Dilakukan & 42 & 51,2 \\
\hline Total & 82 & 100 \\
\hline
\end{tabular}

Tabel 1 diatas menunjukan bahwa responden dengan tingkat pendidikan terakhir terbesar adalah pada tingkat pendidikan SMA yaitu sejumlah 33 responden (40,2\%),jenis kelamin dengan distribusi frekuensi terbesar adalah pada laki-laki yaitu sebesar47 responden $(57,3 \%)$, tingkat usia responden terbanyak adalah pada tingkat usia dewasa yaitu sebesar 49 responden (59,8\%),kadar haemoglobin terbesar adalah pada responden dengan kategori anemia berjumlah $71(86,6 \%)$,suhu responden terbesar adalah pada kategori suhu normal yaitu sebesar 78 $(95,1 \%)$ tekanan darah responden terbesar adalah pada kategori dengan nilai normotensi sebesar 62 responden (75,6\%),tingkat nyeri terbesar adalah pada kategori sedang yaitu sebesar 50 (61,0\%),lokasi fraktur terbesar adalah pada kategori lokasi fraktur di area proksimal yaitu sebesar 39 (47,6\%), waktu rentang operasi terbessar adalah pada kategori responden dengan waktu rentang operasi cepat yaitu sebesar $48 \quad(58,5 \%)$ dan distribusi frekuensi terbesar pada variabel ambulasi dini adalah pada kategori melakukan ambulasi dini sebanyak 42 responden $(51,2 \%)$

\section{B. Bivariat}

\section{a. Pengaruh pendidikan terhadap ambulasi dini}

Tabel 2. Pengaruh pendidikan terhadap ambulasi dini pasien post ORIF pada pasien fraktur femur

\begin{tabular}{ccccccccc}
\hline \multirow{2}{*}{$\begin{array}{c}\text { Pendi- } \\
\text { dikan }\end{array}$} & & \multicolumn{4}{c}{ Ambulasi } & \multirow{2}{*}{ Jumlah } & \\
\cline { 4 - 6 } & & Tidak & \multicolumn{3}{c}{ Ya } & & & \multirow{2}{*}{ Ya } \\
& $\mathrm{f}$ & $\mathrm{f}$ & $\%$ & $\mathrm{f}$ & $\%$ & $\mathrm{p}$ \\
\hline SD & 24 & 29,3 & 7 & 8,5 & 31 & 37,8 & 0.000 \\
SMP & 3 & 3,7 & 7 & 8,5 & 10 & 12,2 & \\
SMA & 7 & 8,5 & 26 & 31,7 & 33 & 40,2 & \\
PT & 6 & 7,3 & 2 & 2,4 & 8 & 9,7 & \\
\hline Jumlah & 40 & 48,8 & 42 & 51,2 & 82 & 100 & \\
\hline
\end{tabular}

Tabel 2 menujukkan Hasil penelitian ini sebagian besar tingkat pendidikan responden adalah pada tingkat SMA yaitu sebesar 33 responden $(40,2 \%)$ dan yang melakukan ambulasi dini sebesar 26 $(31,7 \%)$. Hasil uji chi-square didapatkan $p=0,000$ menunjukan ada pengaruh yang significan antara variabel tingkat pendidikan dengan ambulasi dini post ORIF pada pasien fraktur femur.

Menurut

Notoadmodjo(2010) mengatakan bahwatingkat pendidikan seseorang akanmempengaruhi pengetahuannya. Pendidikandapat membawa wawasan atau pengetahuanseseorang yang mempunyai 
tingkat pendidikanyang tinggi akan mempunyai pengetahuanyang luas bila dibandingkan dengan tingkatpendidikan yang lebih rendah

Menurut Bruner \&Suddarth(2002) menyatakan bahwa pasien yang sudah diajarkan mengenai gangguan muskuloskeletal akan mengalami peningkatan alternatif penanganan. Informasi mengenai apa yang diharapkan termasuk sensasi selama dan setelah penanganan misalnya adanya balutanh dapat memberanikan pasien untuk berpartisipasi secara aktif dalam pengembangan dan penerapan perawatan.

Tingkat pendidikan yang semakin tinggi disertai dengan pemahaman tentang pentingnya mobilisasi juga akan meningkatkan kemampuan klien melakukan mobilisasi. Klien dengan tingkat pendidikan rendah membutuhkan edukasi yang lebih ekstra dari tenaga kesehatan untuk memahamkan pentingnya mobilisasi.

\section{b. Pengaruh jenis kelamin terhadap ambulasi dini}

Tabel 3. Pengaruh jenis kelamin terhadap ambulasi dini pasien post ORIF pada pasien fraktur femur

\begin{tabular}{|c|c|c|c|c|c|c|c|}
\hline \multirow{3}{*}{$\begin{array}{l}\text { Jenis } \\
\text { Kelamin }\end{array}$} & \multicolumn{4}{|c|}{ Ambulasi Dini } & \multirow{2}{*}{\multicolumn{2}{|c|}{ Jumlah }} & \multirow[t]{3}{*}{$p$} \\
\hline & \multicolumn{2}{|c|}{ Tidak } & \multicolumn{2}{|c|}{$\mathrm{Ya}$} & & & \\
\hline & $\mathrm{f}$ & $\%$ & $\mathrm{f}$ & $\%$ & $\mathrm{f}$ & $\%$ & \\
\hline Laki-laki & 18 & 22 & 29 & 35,4 & 47 & 57,4 & 0.028 \\
\hline perempuan & 22 & 26,8 & 13 & 15,8 & 35 & 42,6 & \\
\hline Jumlah & 40 & $\begin{array}{l}48 \\
, 8\end{array}$ & 42 & 51,2 & 82 & 100 & \\
\hline
\end{tabular}

Tabel 3. menunjukan bahwa sebagian besar jenis kelamin responden adalah laki-laki 47 $(57,4 \%)$ dan yang melakukan ambulasi dini sebesar $29(35,4 \%)$. Hasil uji chi-square didapatkan $p=0,028$ menunjukan ada pengaruh yang significan antara variabel jenis kelamin dengan ambulasi dini post ORIF pada pasien fraktur femur

Penelitian ini sejalan dengan penelitian tuti (2013) dimana terdapat hubungan antara jenis kelamin dengan ambulasi dini dengan nilai p-value 0,001.Berkaitan dengan ambulasi dini perempuan lebih cemas akan ketidakmampuannya melakukan ambulasi dini dibandingkan laki-laki, laki-laki lebih aktif dan ekploratif sedngkan perempun lebih sensitif.

Jenis kelamin laki-laki memiliki kekuatan otot yang lebih baik dibandingkan perempuan, sehingga pada pelaksanaan ambulasi dini, laki-laki akan lebih kuat dalam melakukan setiap tahap ambulasi.

c. Pengaruh usia terhadap ambulasi dini

Tabel 4. Pengaruh usiaterhadap ambulasi dini pasien post ORIF pada pasien fraktur femur

\begin{tabular}{lllllllll}
\hline & \multicolumn{4}{c}{ Ambulasi } & & \multirow{2}{*}{ Jumlah } & $p$ \\
\cline { 3 - 8 } Usia & \multicolumn{2}{c}{ Tidak } & \multicolumn{3}{c}{ Ya } & & & \\
& $\mathrm{f}$ & $\%$ & $\mathrm{f}$ & $\%$ & $\mathrm{f}$ & $\%$ & \\
\hline remaja & 0 & 0 & 10 & 12,2 & 10 & 12,2 & 0.000 \\
dewasa & 17 & 20,7 & 32 & 39 & 49 & 59,7 & \\
Lansia & 23 & 28,1 & 0 & 0 & 23 & 28,1 & \\
\hline Jumlah & 40 & 48.8 & 42 & 51,2 & 82 & 100 & \\
\hline
\end{tabular}

Tabel 4. menunjukan bahwa sebagian besar usia responden dengan kategori rentang usia dewasa yaitu 49 responden $(59,7 \%)$ dan yang melakukan sebanyak 32 responden (39\%). Hasil uji chi-square didapatkan $p=0,000$ dimana nilai $p$ value $<0,05$ menunjukan ada pengaruh antara variabel usia dengan ambulasi dini post ORIF pada pasien fraktur femur

Hasil penelitian ini sejalan dengan penelitian Tuti (2013) tentang factor-faktor yang mempengaruhi motivasi ambulasi dini bahwa usia mempengaruhi motivasi pelaksanaan ambulasi dini dengan $p=0,001$

Seorang anak akan berbeda tingkat kemampuan ambulasinya dibandingkan dengan seorang remaja. Usia berpengaruh terhadap kemampuan seseorang dalam melakukan ambulasi. Pada individu lansia, kemampuan untuk melakukan aktivitas dari ambulasi menurun sejalan dengan penuaan.

pada orang dewasa berpendapat bahwa mobilisasi merupakan sesuatu yang harus mereka lakukan setelah tindakan pembedahan selesai dilakukan. Pasien dewasa tua menganggap bahwa mobilisasi pasca bedah dengan resiko terjadinya nyeri merupakan komponen alamiah yang harus mereka terima dari penyembuhan sehingga 
keluhan sering diabaikanKozier (2010). Faktor yang dapat mempengaruhi orang yang berusia dewasa melakukan mobilisasi pasca bedah adalah rasa takut akan kehilangan kemandirian. Orang dewasa cenderung tidak mau menyusahkan orang lain dan berusaha semaksimal mungkin untuk melakukan apapun secara mandiriLeMone \& Burke(2008).

\section{d. Pengaruh Hb terhadap ambulasi dini}

Tabel 5. Pengaruh $\mathrm{Hb}$ terhadap ambulasi dini pasien post ORIF pada pasien fraktur femur

\begin{tabular}{ccccccccc}
\hline & \multicolumn{4}{c}{ Ambulasi } & \multirow{2}{*}{ Jumlah } & $p$ \\
\cline { 3 - 7 } HB & \multicolumn{3}{c}{ Dini } & & & \\
& $\mathrm{f}$ & $\%$ & $\mathrm{f}$ & $\%$ & $\mathrm{f}$ & $\%$ & \\
\hline Normal & 2 & 2,4 & 9 & 11 & 11 & 13,4 & 0.029 \\
Anemia & 38 & 46,4 & 33 & 40,2 & 71 & 86,6 & \\
\hline Jumlah & 40 & 48,8 & 42 & 51,2 & 82 & 100 & \\
\hline
\end{tabular}

Tabel 5. menunjukan bahwa sebagian besar responden dengan kategori anemia yaitu sebesar $71(86,6 \%)$ dan yang tidak melakukan ambulasi dini post ORIF pada pasien fraktur femur sebesar $38(46,4 \%)$ responden. .Hasil uji chi-square didapatkan $p=0,029$ dimana nilai $p$ - <0,05 menunjukan ada pengaruh antara hb dengan ambulasi dini post ORIF pada pasien fraktur femur.

Hasil penelitian ini sejalan dengan penelitian yanti (2009) tentang faktor-faktor yang mempengaruhi pelaksanaan ambulasi dini pasien paska operasi fraktur ekstremitas bawah, dimana hasil penelitian menunjukan ada pengaruh $\mathrm{Hb}$ dengan pelaksanaan ambulasi dini dengan $\mathrm{p}$-value $=0,026$.

Seseorang dengan nutrisi kurang, akan menyebabkan kelemahan dan kelelahan otot yang berdampak pada penurunan aktivitas dan pergerakan. Setiap orang dalam melakukan mobilisasi jelas memerlukan tenaga dan energi, orang yang sedang sakit akan berbeda mobilitasnya dibandingkan orang yang sehat. Pasien dengan anemia menunjukan adanya defisit atau tidak adekuatnya nutrisi, sehingga sering mengalami atropi otot, penurunan jaringan subkutan yang serius, dan gangguan keseimbangan cairan dan elektrolit. Pasien juga akan mengalami defisiensi protein, keseimbangan nitrogen dan tidak adekuatnya vitamin $\mathrm{C}$ sehingga mempengaruhi kemampuan mobilisasi atau aktifitas Kozier (2010).

Trauma ataupun metode operasi pada fraktur batang femur yang menimbulkan perdarahan akut dalam jumlah besar, bisa menimbulkan penurunan kadar hemoglobin akibat ketidakmampuan tubuh memproduksi sel darah merah yang cukupNagra, ett,all (2016).Jadi pasien yang mengalami anemia penurunan $\mathrm{Hb}$ tidak akan tahan melakukan ambulasi karena cepat lelah dan pusing. Ini juga sejalan dengan pendapat Potter \& Perry yang menyatakan bahwa seseorang yang mengalami sakit kepala ringan, pusing, kelemahan, kelelahan, kehilangan energi, dispnue dan hampir pingsan kurang mampu untuk melakukan aktivitas seperti ambulasiKozier (2010). kelelahan yang berlebihan bisa menyebabkan pasien jatuh atau mengalami ketidak seimbangan pada saat latihan

e. Pengaruh suhu terhadap ambulasi dini Tabel 6. Pengaruh Hb terhadap ambulasi dini pasien post ORIF pada pasien fraktur femur

\begin{tabular}{|c|c|c|c|c|c|c|c|}
\hline \multirow{3}{*}{ Suhu } & \multicolumn{4}{|c|}{ Ambulasi Dini } & \multirow{2}{*}{\multicolumn{2}{|c|}{ Jumlah }} & \multirow{3}{*}{$p$} \\
\hline & \multicolumn{2}{|c|}{ Tidak } & \multicolumn{2}{|c|}{$\mathrm{Ya}$} & & & \\
\hline & $\mathrm{f}$ & $\%$ & $\mathrm{f}$ & $\%$ & $\mathrm{f}$ & $\%$ & \\
\hline Hipotermi & 3 & 3,6 & 0 & 0 & 3 & 3,6 & \\
\hline Normal & 36 & 44 & 42 & 51,2 & 78 & 95,2 & 0.110 \\
\hline Hipertermi & 1 & 1,2 & 0 & 0 & 1 & 1,2 & \\
\hline Jumlah & 40 & 48,8 & 42 & 51,2 & 82 & 100 & \\
\hline
\end{tabular}

Tabel 6. bahwa sebagian besar suhu responden dalam kategori normal yaitu 78 $(95,1 \%)$, dan yang tidak melakukan ambulasi dini post ORIF pada pasien fraktur femur sebesar 36 (44\%) responden. Hasil uji chi-square didapatkan $p=0,110$ dimana nilai $p$ - $>0,05$ menunjukan tidak ada pengaruh antara suhu dengan ambulasi dini postORIF pada pasien fraktur femur.

Penelitian ini sejalan dengan penelitian Hernawily (2012) tentang faktor yang berkontribusi pada pelaksanaan ambulasi dini pasien fraktur ekstremitas bawah dengan hasil tidak terdapat hubungan antara 
suhu dengan ambulasi dini post operasi dengan $p$-value $=0,341$. Penelitian ini juga sejalan dengan penelitian yang dilakukan Yanti (2009) bahwa tidak terdapat pengaruh antara suhu dengan pelaksanaan ambulasi dini pasien paska operasi fraktur ekstremitas bawah.

Pasien yang lemah tidak akan mampu untuk melakukan latihan ambulasi, karena ambulasi yang aman memerlukan keseimbangan dan kekuatan yang cukup untuk menopang berat badan dan menjaga postur tubuhHoeman (2001).

\section{f. Pengaruh tekanan darah terhadap ambulasi dini}

Tabel 7. Pengaruh tekanan darah terhadap ambulasi dini pasien post ORIF pada pasien fraktur femur

\begin{tabular}{|c|c|c|c|c|c|c|c|}
\hline \multirow{3}{*}{ TD } & \multicolumn{4}{|c|}{ Ambulasi Dini } & \multirow{2}{*}{\multicolumn{2}{|c|}{ Jumlah }} & \multirow{3}{*}{$p$} \\
\hline & \multicolumn{2}{|c|}{ Tidak } & \multicolumn{2}{|c|}{$\mathrm{Ya}$} & & & \\
\hline & $\mathrm{f}$ & $\%$ & $\mathrm{f}$ & $\%$ & $\mathrm{f}$ & $\%$ & \\
\hline Hipotensi & 2 & 2,4 & 3 & 3,7 & 5 & 6,1 & 0.301 \\
\hline Normotensi & 28 & 31,2 & 34 & 41,4 & 62 & 72,6 & \\
\hline Hipertensi & 10 & 15,2 & 5 & 6,1 & 15 & 21,3 & \\
\hline Jumlah & 40 & 48,8 & 42 & 51,2 & 82 & 100 & \\
\hline
\end{tabular}

bahwa dalam penelitian didapatkan hasil pada responden dengan hipotensi sebesar 3 $(3,7 \%)$ yang melakukan ambulasi dini post ORIF pada pasien fraktur femur dan 2 $(2,4 \%)$ tidak melakukan ambulasi dini post ORIF pada pasien fraktur femur. Pada responden dengan tekanan darah normal atau normotensi sebesar $34 \quad(41,4 \%)$ responden yang melakukan ambulasi dini post ORIF pada pasien fraktur femur sedangkan yang tidak melakukan sebanyak $28(31,2 \%)$ responden. Selanjutnya pada responden dengan hipertensi terdapat 5 $(6,1 \%)$ responden yang melakukan ambulasi dini post ORIF pada pasien fraktur femur, dan sebesar $10(15,2 \%)$ responden yang tidak melakukan ambulasi dini post ORIF pada pasien fraktur femur. Secara statistik penelitian ini tas menyatakan tidak ada hubungan antara tekanan darah dengan perilaku ambulasi dini post ORIF pada pasien fraktur femur dengan $p$ value 0,301.

Penelitian ini sejalan dengan penelitian Yanti (2010) yang memperlihatkan bahwa kondisi kesehatan yang normal tidak mempengaruhi pelaksanaan ambulasi dini pasien paska operasi. Pada penelitian ini sebagian besar responden memiliki tekanan darah normal yang seharusnya memungkinkan untuk melakukan ambulasi dini.

Tidak semua pasien setelah pembedahan dapat segera melakukan mobilisasi dini, umumnya pasien post operasi setelah 24 jam lebih memilih untuk diam ditempat tidur (bedrest). Hipotensi ortostatik sering menyebabkan pasien kurang melakukan aktivitas seperti ambulasi dini. Pada penelitian ini sebagian besar responden memiliki tekanan darah normal tetapi masih banyak yang tidak melakukan ambulasi dini.

g. Pengaruh nyeri terhadap ambulasi dini Tabel 8. Pengaruh nyeri terhadap ambulasi dini pasien post ORIF pada pasien fraktur femur

\begin{tabular}{lllllllll}
\hline \multirow{2}{*}{ Nyeri } & \multicolumn{9}{c}{ Ambulasi Dini } & \multirow{2}{*}{ Tumlah } & \multirow{2}{*}{$p$} \\
& $\mathrm{f}$ & $\%$ & $\mathrm{f}$ & $\%$ & $\mathrm{f}$ & $\%$ & \\
\cline { 1 - 5 } Ringan & 4 & 4,9 & 8 & 9,7 & 12 & 14,6 & \\
Sedang & 19 & 23,2 & 31 & 37,8 & 50 & 61 & 0.001 \\
Berat & 17 & 20,7 & 3 & 3,7 & 20 & 24,4 & \\
\hline Jumlah & 40 & 48,8 & 42 & 51,2 & 82 & 100 & \\
\hline \multicolumn{5}{c}{ Tabel } & 8, & menunjukan & bahwa & sebagian
\end{tabular}
besar nyeri responden dalam kategori sedang yaitu $50(61 \%)$ dan yang melakukan ambulasi dini post ORIF pada pasien fraktur femur sebesar $31(37,8 \%)$ responden. Secara statistik penelitian ini menyatakan ada hubungan antara nyeri dengan perilaku ambulasi dini post ORIFpada pasien fraktur femur dengan p 0,001.

Hasil penelitian ini sejalan dengan penelitian Martinah (2009) tentang pelaksanaan ambulasi dini pada pasien post operasi dengan hasil ada hubungan yang bermakna antara nyeri dengan terlaksananya ambulasi dinyatakan dengan hasil statistik yaitu $p$-value $=0,01$. Penelitian ini juga selaras dengan hasil penelitian Yunilda (2017) ada hubungan antara nyeri dengan pelaksanaan ambulasi dini $p$-value $=0,00$.

Masalah sering terjadi post operasi adalah ketika pasien merasa terlalu sakit atau nyeri dan faktor lain yang menyebabkan mereka tidak mau melakukan ambulasi dini dan memilih 
untuk istirahat di tempat tidurKozier, dkk(2010). Beberapa pasien menyatakan bahwa nyerinya lebih ringan dibanding sebelum pembedahan dan hanya memerlukan jumlah analgetik yang sedikit saja, harus diupayakan segala usaha untuk mengurangi nyeri dan ketidaknyamanan. Obat harus diberikan segera dalam interval yang ditentukan bila awitan nyeri dapat diramalkan misalnya $1 / 2$ jam sebelum aktivitas terencana seperti pemindahan dan latihan ambulasiBrunner \& Suddarth (2010).

Kebanyakan pasien merasa takut untuk bergerak setelah paska operasi fraktur karena merasa nyeri pada luka bekas operasi dan luka bekas trauma. Selanjutnya pasien yang mengalami nyeri post operasi menjadi ragu untuk melakukan batuk, nafas dalam, mengganti posisi, ambulasi atau melakukan latihan yang diperlukanSmeltzer\& Bare (2013).

\section{h. Pengaruh lokasi fraktur terhadap ambulasi dini}

Tabel 9. Pengaruh lokasi fraktur terhadap ambulasi dini pasien post ORIF pada pasien fraktur femur

\begin{tabular}{|c|c|c|c|c|c|c|c|}
\hline \multirow{3}{*}{$\begin{array}{l}\text { Lokasi } \\
\text { Fraktur }\end{array}$} & \multicolumn{4}{|c|}{ Ambulasi } & \multicolumn{2}{|c|}{ Jumlah } & \multirow[t]{3}{*}{$p$} \\
\hline & \multicolumn{2}{|c|}{ Tidak } & \multicolumn{2}{|c|}{$\mathrm{Ya}$} & & & \\
\hline & $\mathrm{f}$ & $\%$ & f & $\%$ & $\mathrm{f}$ & $\%$ & \\
\hline Proksimal & 26 & 31,7 & 13 & 15,8 & 39 & 47,6 & \\
\hline Medial & 7 & 8,5 & 18 & 22 & 25 & 30,5 & 0.007 \\
\hline Distal & 7 & 8,5 & 11 & 13,4 & 18 & 21,9 & \\
\hline Jumlah & 40 & 48,8 & 42 & 51,2 & 82 & 100 & \\
\hline
\end{tabular}

besar lokasi fraktur responden adalah pada bagian proksimal yaitu sebesar $39(47,6 \%)$ dan yang tidak melakukan ambulasi dini post ORIF pada pasien fraktur femur sebesar $26(31,7 \%)$. Secara statistik penelitian ini menunjukan ada pengaruh antara lokasi fraktur dengan perilaku ambulasi dini post ORIF pada pasien fraktur femur dengan $p 0,007$.

Femur merupakan tulang paling panjang dan kuat dan yang dapat dibagi menjadi 3 bagian: proksimal, median, dan distal. Bagian proksimal terdiri dari kepala, leher, dan trochanter ${ }^{35}$.Kepala femur terdapat dalam acetabulum pada pelvis.Kepala femur mempunyai ukuran yang bervariasi tergantung proporsi IMT (Indeks Massa Tubuh) dan kirakira berdiamater kisaran 38-58 $\mathrm{mm}$ menutupi ligamen kartilago dengan rata-rata ketebalannya 3-4 mm2.Pada fraktur intertrochanter merupakan fraktur yang paling sering di operasi dengan fatality rate pasca operasi yang tinggi, serta menjadi beban ekonomi yang berat akibat biaya perawatan pasca trauma yang tinggi. Alasan mengenai tingginya biaya perawatan, diakibatkan buruknya waktu penyembuhan pasien pasca operasi untuk kembali dapat melakukan mobilisasi secara mandiriCanale (2008)

Collum femur paling sempit ada pada bagian tengahnya dan bagian paling lebar adalah pada bagian lateral. Collum menghubungkan caput terhadap corpus femur dengan sudut inklinasi (Neck Shaft Angle) kurang lebih $125^{\circ}$, hal ini memfailitasi pergerakan pada sendi coxae dimana tungkai dapat mengayun secara bebas terhadap pelvis

\section{i. Pengaruh waktu rentang operasi terhadap ambulasi dini}

Tabel 10. Pengaruh suhu terhadap ambulasi dini pasien post ORIF pada pasien fraktur femur

\begin{tabular}{lccccccc}
\hline & \multicolumn{4}{c}{ Ambulasi } & & & \\
\multirow{nnnyyyyn}{*}{ W.R.O } & \multicolumn{2}{c}{ Dini } & & Jumlah & $p$ \\
& fidak & $\%$ & f & $\%$ & f & $\%$ & \\
\hline Cepat & 20 & 24,4 & 28 & 34,1 & 48 & 58,5 & 0.126 \\
Lambat & 20 & 24,4 & 14 & 17,1 & 34 & 41,5 & \\
\hline Jumlah & 40 & 48,8 & 42 & 51,2 & 82 & 100 & \\
\hline
\end{tabular}

Tabel 10. Menujukkan tidak ada hubungan antara waktu rentang operasi dengan perilaku ambulasi dini post ORIF pada pasien fraktur femur dengan $p=0,126$

Menurut Potter\& Perry (2010) pada penelitianya The Timing Of Surgery For Proximal Femoral Fracture bahwa dari 4 karakteristik responden berdasarkan waktu admisi operasi hasilnya yaitu rata-rata mobilisasi untuk group <24 jam adalah 5,3 group $24 \mathrm{~s} / \mathrm{d} 47$ jam nilai rata-rata mobilisasinya adalah 4,8 group $48 \mathrm{~s} / \mathrm{d} 72$ jam adalah 5,5 dan group $>72$ jam nilai rata-rata mobilisasinya adalah 4,5

Waktu dilakukannya pembedahan adalah salah satu faktor yang dapat dimodifikasi serta memiliki dampak terhadap kemampuan pasien untuk kembali ke aktivitas sehari-hari.Hubungan antara waktu dilakukannya pembedahan fraktur proksimal femur dengan hasil akhir operasi telah menjadi subjek penelitian untuk waktu yang lama.Waktu penundaan operasi yang singkat berkaitan dengan penurunan tingkat komplikasi 
paska operasi.Telah dipublikasikan bahwa operasi yang dilakukan sedini mungkin (dalam 24 hingga 36 jam paska admisi ke rumah sakit) berhubungan dengan komplikasi paska operasi yang lebih minimal (pneumoni, konfusi, ulkus decubitus) dan waktu tinggal di rumah sakit yang lebih singkat.Namun, operasi yang dini tidak memperpanjang harapan hidup pasien.Hal ini sesuai dengan yang diungkapkan oleh Amer bahwa penundaan waktu operasi akan menyebabkan waktu imobilisasi yang lebih panjang dan dapat menginduksi proses atrofi pada otot (Zuckerman J.D, 1995).

\section{Multivariat}

Tabel 11. Hasil analisis Regresi Logistik

\begin{tabular}{|c|c|c|c|c|}
\hline \multirow[t]{2}{*}{ Variabel } & \multirow[t]{2}{*}{ Sig. } & \multirow[t]{2}{*}{ Exp } & \multicolumn{2}{|c|}{$\begin{array}{c}\text { 95,0\% C.I.for } \\
\text { EXP(B) }\end{array}$} \\
\hline & & & Lower & Upper \\
\hline $\mathrm{Hb}$ & .014 & .101 & .016 & .624 \\
\hline Nyeri & .002 & .230 & .089 & .591 \\
\hline $\begin{array}{l}\text { Lokasi } \\
\text { Fraktur }\end{array}$ & .023 & 2.140 & 1.113 & 4.117 \\
\hline Constant & .006 & 450.438 & & \\
\hline
\end{tabular}

Tabel 4.30 menujukkan bahwa dari keseluruhan proses analisis yang telah dilakukan dapat disimpulkan bahwa dari 7 (tujuh) variabel independent yang diduga berpengaruh terhadap ambulasi dini post ORIF pada pasien fraktur femur ternyata hanya ada 3 (tiga) yang secara signifikan berpengaruh yaitu variabel $\mathrm{Hb}(\mathrm{p}$ value $=0.014)$, nyeri $(\mathrm{p}$ value $=0.002)$ dan $L F(p$ value $=0.023)$.

\section{SIMPULAN}

Berdasarkan hasil penelitian yang dilakukan pada 82responden post ORIF pada pasien fraktur femur di RSU Siaga Medika Banyumas didapatkankesimpulan :sebagian besar responden melakukan ambulasi dini post ORIF pada pasien fraktur femur. Hasil uji regresi logistik didapatkan 3 faktor yang berpengaruh secara significan yaitu faktor $\mathrm{Hb}$ dengan nilai $p=0,014$ dan dengan OR 0,101 , kemudian faktor nyeri $p=0,002$ dengan OR 0,230 dan lokasi fraktur yang paling berpengaruh terhadap ambulasi dini post ORIF pada pasien fraktur femur. Faktor lokasi fraktur memiliki ods ratio $p=0.023$, dengan nilai $\mathrm{OR}$ 2.140 dan dapat disimpulkan bahwa lokasi fraktur merupakan factor yang paling berpengaruh terhadap ambulasi dini post ORIF pada pasien fraktur femur.
Diharapkan bagi perawat untuk mengkaji faktor-faktor apa saja dan faktor yang paling dominan yang mempengaruhi pelaksanaan ambulasi dini post ORIF pada pasien fraktur femur sebelum memberikan intervensi ambulasi dini.

\section{DAFTAR PUSTAKA}

Brunner \& Sudarth, B.A.R. (2010). Buku Ajar Keperawatan Medical Bedah, Edisi ke 12. Jakarta :EGC

Canale T, Beaty JH. (2008). Campbell's Operative Orthopaedic: Fracture of the Hip (11 ${ }^{\text {th }}$ Ed). Philadelphia: Mosby Elsevier.

Hernawily. (2012). Faktor Yang Berkontribusi Pada Pelaksanaan Ambulasi Dini Pasien Fraktur Ekstremitas Bawah. Jurnal Keperawatan, Volume VIII, No. 2, Oktober 2012. ISSN 1907 - 0357

Hoeman, S.P. 2001. Rehabilitation nursing (process application \& out comes). (3th edition). United States of America: Mosby Inc.

Keehan, R., Kendrick, E., Flavell, E., Deglurkar, M. 2014. Enhanced recovery for fractured neck of femur: a report of 3 cases. Geriatric orthopaedic surgery \& rehabilitation. Vol. 5 (2), 37 - 42.

Kozier, B., dkk. 2010. Buku Ajar Fundamental Keperawatan: Konsep, proses, \& praktik (7th ed, 2nd vol.). Jakarta: Buku Kedokteran EGC.

LeMone, P, \& Burke.(2008). Medical surgical nursing : Critical thinking in clientcare.( 4th ed). Pearson Prentice Hall : New Jersey

Martinah(2009). Pelaksanaan Ambulasi dini pada pasien post operasi, Palembang

Nagra, N. S, van Popta, D, Whiteside, S, \& Holt, E. M. (2016). analysis of postoperative hemoglobin levels in patients with a fractured neck of femur. Acta Orthopaedica et Traumatologica Turcica, 50(5), 507-513

Notoatmodjo, S. (2010). Metodologi penelitian kesehatan. Jakarta: Rineka Cipta 
Obaidurrahman,et,all. 2013. Patern of Femoral Fractures . Journal of Rawalpindi Medical College (JRMC). Vol 17. no 1

Price \& Wilson, 2012. Patofisiologi: konsep klinis proses-proses penyakit.Jakarta: EGC

Potter, P.A. \& Perry, AG. 2010. Fundamental keperawatan, Edisi 7,Buku 2 Jakarta: EGC

Satia. 2011. Faktor-Faktor Yang Mempengaruhi Pelaksanaan Ambulasi Dini Pada Pasien Pasca Operasi Fraktur Ekstremitas Bawah

Smeltzer, SC \& Bare BG. (2013). Buku ajar keperawatan medikal bedah. Jakarta: EGC

Tita. 2013. Gambaran implementasi mobilisasi dini oleh perawat pada klien post operasi fraktur ekstremitas bawah di RSUP Fatmawati

Tuti, dkk. (2013). Analisis factor-faktor yang berhubungan dengan motivasi mobilisasi dini pada pasien pasca bedah digestif di RSUD Serang

Yanti, N. M (2009). Analisis Faktor-Faktor Yang Mempengaruhi PelaksanaanAmbulasi Dini Pasien Paska Operasi Fraktur Ekstremitas Bawah di rinduB3 RSUP. H Adam Malik Medan

Yunilda, dkk. (2017). Faktor-Faktor Yang Berhubungan Dengan Pelaksanaan Ambulasi Dini Pada Pasien Post Operasi Diruang Rawat InapRsi Siti Khadijah Palembang

Zuckerman J.D. (1995). Postoperative Complications and Mortality Associated with Operative Delay in Older Patients Who Have a Fracture of the Hip. The Journal of Bone and Joint Surgery, 77$\mathrm{A}(10)$ : 1551-1556. 